respectively. The stations are anxious to receive reports of the finding of these birds in any part of the world with the view of gaining further information as to bird migration and other phenomena of bird life. They will gratefully acknowledge all such reports, and are prepared to furnish in reply information not only as regards the bird in question, but also as regards their work generally. Reports will be sufficiently addressed if directed to Vogelwarte Helgoland, Germany, or Vogelwarte Rossitten, Germany.

\section{Federation of Scientific Societies in Australia}

The Australian National Research Council, having come to the conclusion, at a general meeting last January, that it is not properly fulfilling its function as a national body representative of scientific thought and endeavour, will, during this year, examine the possibilities of effecting a federation of the various State Royal Societies, the Linnean Society of New South Wales, and a number of professional organisations such as the Australian Chemical Institute, the Institute of Physics, the Institution of Engineers and the Australian Veterinary Association. The federation will be confined to bodies concerned with the physical and biological sciences. No constitution has yet been suggested, but the general proposal is that each constituent member shall retain its independence as at present and shall have the right to representation on the Federal Council. The nature of the representation and the definition of duties of the council will be the subject of discussion at a conference of delegates from the interested societies, to be called later by the present National Research Council.

\section{Announcements}

ThE council of the Royal Society of Edinburgh has awarded the Makdougall-Brisbane Prize for the period 1932-34 to Dr. A. E. Cameron, lecturer in entomology, University of Edinburgh, for his publications in entomology, including his recent paper in the Transactions, "The Life-History and Structure of Hoematopota pluvialis Linné (Tabanidæ)".

The Prime Minister will open a Noise-Abatement Exhibition at the Science Museum, South Kensington, on May 31 at 11 a.m.

THE annual meeting of the Swiss Röntgen Society will be held at Montreux on June 15 and 16. Further information can be obtained from Dr. A. Grosjean, La Chaux de Fonds, Switzerland.

THE sixteenth annual congress of the German Association for Microbiology will be held in Berlin on May 26-28, when the subjects for discussion will be diphtheria and piroplasmiasis.

Following the announcement that the Australian Government will erect a laboratory in Melbourne for the Forest Products Division of the Council for Scientific and Industrial Research, Mr. W. Russell
Grimwade has offered to provide $£ 5,000$ for the purchase of additional apparatus and equipment for the new building.

THE following appointments have recently been made by the Secretary of State for the Colonies : Mr. A. M. Gwynn, entomologist, Agricultural Department, Nigeria, to be assistant entomologist, Agricultural Department, Uganda; Mr. H. R. Binns, to be veterinary officer, Nyasaland; Mr. R. G. Sangster, to be assistant conservator of forests, Uganda ; $\mathrm{Mr}$. J. Gordon, to be inspector of plants and produce, Gold Coast.

The nineteenth National Baby Week will be held on July 1-7. The subjects for propaganda during 1935 will be the welfare of the pre-school child and the good nutrition of mothers and children. On July 1-3 a conference on "Maternity and Child Welfare", organised by the National Association for the Prevention of Infant Mortality, will be held in London. Further information can be obtained from the Secretary, National Baby Week Council, 117 Piccadilly, London, W.1.

THe Institution of Electrical Engineers is making arrangements for a summer meeting to be held in Belgium, probably on September 8-14. The programme will include excursions and visits to works, and among the towns included in the itinerary will be Brussels (which will probably be the headquarters town and where the Exhibition will still be in progress), Antwerp, Charleroi, Dinant, Langebrugge, Liège, Tirlemont, and also Ypres and other places in the battlefields of the War.

Applications are invited for the following appointments, on or before the dates mentioned :-An assistant at the Coal Survey Laboratory, Nottingham - The Establishment Officer, Department of Scientific and Industrial Research, 16 old Queen Street, Westminster, S.W.I (May 20). A veterinary investigation officer at the University of Liverpool-The Registrar (May 24). A principal of the Technical College and School of Art, Colchester-The Director of Education, County Offices, Chelmsford (May 25). A science lecturer in the Yorkshire Training College of Housecraft, Leeds--The Director of Education, Education Department, Colverley Street, Leeds (May 28). An assistant in the Natural History Department of the Royal Scottish Museum, Edinburgh-The Director (May 31). A lecturer in geography and geology at St. Luke's College, ExeterThe Principal (May 31). An assistant lecturer in applied electricity and hydro-electric engineering in the University College of North Wales, Bangor-The Registrar (June 8). A lecturer in geography in Armstrong College, Newcastle-upon-Tyne-The Registrar. Assistant engineers for the Drainage and Irrigation Departments of the Governments of the Federated Malay States and Straits SettlementsThe Crown Agents for the Colonies, 4 Millbank, London, S.W.I. 